Article

\title{
The Role of Arrival Areas for Migrant Integration and Resource Access
}

\author{
Heike Hanhörster ${ }^{1, *}$ and Susanne Wessendorf ${ }^{2,3}$ \\ ${ }^{1}$ Urban Social Space Research Group, Research Institute for Regional and Urban Development, 44135 Dortmund, Germany; \\ E-Mail: heike.hanhoerster@ils-forschung.de \\ 2 International Inequalities Institute, London School of Economics and Political Science, London, WC2A 2AZ, UK; \\ E-Mail: s.wessendorf@lse.ac.uk \\ ${ }^{3}$ Centre for Trust, Peace and Social Relations, Coventry University, Coventry, CV1 2TL, UK \\ * Corresponding author
}

Submitted: 12 February 2020 | Accepted: 12 May 2020 | Published: 28 July 2020

\begin{abstract}
Research on socio-economically disadvantaged neighbourhoods with high numbers of migrants tends to problematise such areas as hindering upward social mobility and further enhancing disadvantage. However, an emerging body of research on arrival areas is highlighting how such areas can provide newcomers with specific arrival resources, helping them to come to grips with their new circumstances. This article provides a conceptual overview and discussion of this newly emerging body of literature on urban arrival areas in the Global North. It argues that arrival areas offer infrastructures which can provide important support for newcomers, ranging from overcoming day-to-day problems to potentially enabling social mobility. In many cases, previous migrants act as knowledge brokers facilitating newcomers' access to resources. The article shows how different forms of arrival-specific knowledge can be found in these areas, facilitating the exchange of resources across different migrant groups and across localities. However, arrival-specific infrastructures can be both enabling and disabling with regard to social mobility, as they often emerge in contexts of underlying disadvantage and discrimination where access to resources such as housing and jobs can be highly contentious. The article argues that understanding the dynamics of urban arrival areas and infrastructures and their specific role in providing resources for newcomers can contribute to our knowledge on integration and help us rethink the role of policymaking and urban planning in increasingly complex and mobile urban societies.
\end{abstract}

\section{Keywords}

arrival areas; arrival infrastructures; diversity; integration; migration

\section{Issue}

This article is part of the issue "Urban Arrival Spaces: Social Co-Existence in Times of Changing Mobilities and Local Diversity" edited by Yvonne Franz (University of Vienna, Austria) and Heike Hanhörster (ILS-Research Institute for Regional and Urban Development, Germany).

(C) 2020 by the authors; licensee Cogitatio (Lisbon, Portugal). This article is licensed under a Creative Commons Attribution 4.0 International License (CC BY).

\section{Introduction}

One of the big issues currently facing European societies is the influx of increasing numbers of migrants from various parts of the world. While European states grapple with controlling borders and managing immigration flows, the real challenge faced on the ground is, in fact, the challenge of migrant integration. We understand the contested and increasingly criticised term 'integration' as an analytical concept capturing various forms of access to different functional, social and symbolic resources (Ager \& Strang, 2008). In this conceptual article, we investigate integration through the newly emerging concept of 'arrival infrastructures' (Meeus, Arnaut, \& van Heur, 2019). Arrival infrastructures have been defined as "those parts of the urban fabric within which newcomers become entangled on arrival, and where their future local or translocal social mobilities are produced as much as negotiated" (Meeus et al., 2019, p. 1). We argue that understanding the dynamics of urban arrival areas 
and arrival infrastructures' specific role in providing resources for newcomers can contribute to our knowledge on integration and help us rethink the role of policymaking and urban planning in increasingly diverse and mobile urban societies.

For a long time, policymakers and leading social scientists have been raising the question of how migrants' integration can be affected by living in areas characterised by a combination of high concentrations of ethnic minorities and socio-economic deprivation (Ostendorf \& Musterd, 2011). Research focusing on so-called 'context effects' in deprived neighbourhoods, by nature mainly quantitative, analyses how living in these neighbourhoods can negatively impact local inhabitants' access to resources, affecting their social, economic and cultural capital and limiting their upward social mobility (van Ham \& Manley, 2012).

In the context of the recent refugee crisis, which has exacerbated an already hostile climate where newcomers are politically, socially and spatially marginalised, political debates have intensified across Western Europe, with renewed interest among politicians and planners in the paradigm of social mixing. The underlying assumption in these debates is that the dispersion of migrants/refugees might facilitate their local integration. In European cities, social-mixing and area-based policies have been the main instruments implemented for governing diversity (Galster, 2007). This can be illustrated by the lively and partly heated debate in countries such as Germany, France, the Netherlands and Sweden on policies of refugee dispersal, which ought to prevent (new) 'ethnic concentrations' in specific cities and neighbourhoods and thereby 'distribute the burden' (Adam et al., 2020; ESPON, 2019; Robinson, Andersson, \& Musterd, 2003).

These debates take place within a context where new migrants often move into super-diverse areas already settled by previous migrants from various backgrounds (Vertovec, 2007). These areas, with their long histories of immigration, have also been described as 'arrival areas,' often located in 'arrival cities' which have experienced immigration over many decades (Phillimore, Humphris, \& Khan, 2018; Saunders, 2011). Social realities within such areas can be conducive to migrant settlement, somewhat contradicting current thinking on migrant and refugee dispersal.

Building on literature on 'ethnic enclaves' (Wilson \& Martin, 1982) and discussions on so-called 'neighbourhood effects,' this article shows how the arrival infrastructural lens expands these debates by taking into account the complexities of arrival in increasingly superdiverse arrival areas characterized by the over-layering of ongoing immigration (Vertovec, 2007, 2015). We start by demonstrating that the notion of arrival infrastructures expands the focus on co-ethnic support structures prevalent in the literature on ethnic enclaves, highlighting how newcomers can draw on support from longerestablished migrants, possibly from different ethnic and national backgrounds. Moreover, the provision of support via arrival infrastructures, although often initiated within certain neighbourhoods, can transcend arrival areas. For example, local social connections in arrival areas can provide links to accessible resources transcending neighbourhood boundaries, relativizing the context of multiple disadvantages attributed to many immigrant neighbourhoods (Hanhörster \& Weck, 2016) and discussed in the literature on context effects.

This article aims to describe the characteristics of arrival areas, primarily in the Global North, and the ways in which previous migrants can act as knowledge brokers facilitating newcomers' access to resources. It shows that a focus on arrival infrastructures can help shed light on the multi-directionality and complexities of migrant integration and the fact that urban spaces, both in their complex composition and social dynamics, change in the ongoing processes of arrival.

This article is conceptual rather than empirical, drawing on existing literature and debates on urban areas characterized by high numbers of migrants. It summarises academic discourses on the role of neighbourhoods in migrant integration, focusing in the first section on discussions on 'context effects' and 'ethnic enclaves.' This is followed by an overview of emerging work on 'arrival areas' and 'arrival infrastructures,' and the role of this recent conceptual approach in advancing research on migrant integration.

\section{The Role of the Neighbourhood Context for Integration and Resource Access}

Both academic and political discourses relating to the challenges of migrant integration are often closely associated with the discussion over potential 'context effects' (also known as 'neighbourhood effects'). The neighbourhood context is thereby seen to have an effect extending beyond individual and household-related causes for disadvantage, leading to further disadvantage among residents (van Ham \& Manley, 2012).

Numerous empirical studies-many featuring US cities-have identified a negative influence of neighbourhoods characterised by poverty and social disadvantage on their residents (Galster \& Sharkey, 2017). Many studies of context effects specifically look at three factors shaping resource access: a) physical-spatial structures and the extent to which infrastructures (such as parks, schools or social services) are accessible for inhabitants, b) the conduciveness of an environment for establishing contacts and social networks, and c) effects determined by the neighbourhood's symbolic role and image, and the related question as to what extent residents can develop a sense of belonging to and pride in living in an area (Galster \& Sharkey, 2017). Context effects were similarly found in European neighbourhoods (albeit significantly less ethnically and socially segregated than their US counterparts), though to a lesser extent and with sometimes contradictory findings (van Ham \& Manley, 
2012). Conclusions differ dependent on the spatial scale selected, the cohort observed, the methodology chosen and the length of the observed period (Hans, Hanhörster, Polivka, \& Beißwenger, 2019). Most research into context effects looks mainly at deficits, primarily analysing the negative effects of the neighbourhood.

One of the main problems with research on 'context effects' is that these effects are generally presented in the context of an understanding of a neighbourhood as a spatially limited 'container space' (van Kempen \& Wissink, 2014). It is thereby assumed that the neighbourhood and its local resources play a significant role in determining the social mobility of its residents. This focus on the immediate surroundings does not, however, take sufficient account of current society, its practices and social relationships, which are becoming increasingly translocal and transnational. Migrants often draw on resources which go beyond the neighbourhood, for example via social media, making use of transnational networks allowing them to participate in what is happening in both their home and host countries (Glick Schiller \& Çağlar, 2009; Sametipour, 2017). Studies also point to an increase in temporary forms of migration, a factor influencing migrants' location practices and consequently the development of their networks (Faist, 2015). Such dynamics demonstrate that migrants' networking activities are not limited to their immediate surroundings, but based on multilocal networks (Hanhörster \& Weck, 2016). Thus, both local and transnational networks serve as contexts for accessing resources. Some scholars question neighbourhood effect research altogether because it tends to ignore the broader structural factors which lead to social inequality and poverty in the first place, and does not address shortcomings in investments by the state, for example in education and support in accessing the labour market (Slater, 2013, p. 369).

In addition to the wide research body on context effects in deprived neighbourhoods as a broader discussion not solely affecting migrants, a large number of studies look at areas with a high concentration of residents with a migration background, also referred to as 'ethnic enclaves' (Wilson \& Martin, 1982), 'immigrant enclaves' (Portes \& Manning, 1986) or 'urban enclaves' (Zhou, 2009). Some of these studies conclude that living in 'ethnic enclaves' for a longer period of time can be an obstacle to integration, stressing the disintegrating effect related to socio-economic disadvantage and poor housing, limited social capital with regard to access to individuals with higher educational backgrounds, schools struggling with high numbers of pupils not speaking the majority language, etc. (Ostendorf \& Musterd, 2011). However, other studies see potential integrationrelated benefits in ethnically concentrated urban neighbourhoods (Fajth \& Bilgili, 2018). Such benefits include, for example, the spatial proximity to family and co-ethnic (social) support networks, to migrant-specific businesses or other migration-related infrastructures, as well as the potential positive effect of small-scale integration on sol- idarity and self-confidence (Zhou, 2009). For example, Vaughan's historical research on Jewish immigrant settlements in London's East End illustrates how physical clustering can be beneficial for mutual support and for setting up niche economic activities within the immigrant group. Locations enabling economic activity are highlighted as an important precondition for migrants' successful arrival and social mobility. In addition to the availability of work, access to affordable housing makes such districts attractive to the immigrant poor (Vaughan, 2007, p. 6).

More recent studies have similarly shown how social disadvantage in areas with high numbers of migrants can be relativized by various factors such as the diversity of newcomers, their social ties extending beyond the neighbourhood, and people remaining in the neighbourhood despite having moved up the social ladder. For example, descendants of migrants (the second and third generation) can act as important brokers for newcomers. Qualitative research has shown that social mobility does not necessarily go hand in hand with spatial mobility and that migrants do not need to leave their neighbourhood to climb up the social ladder (Barwick, 2016; Hanhörster, 2015). In fact, many upwardly mobile migrants and their descendants explicitly choose to stay in their neighbourhood. Through purchasing property or setting up a business, 'old hands' can make resources such as housing or services available to newcomers of various backgrounds (Erel, 2011). For example, research on residential location choices of Turkish-origin homeowners in the Ruhr area (Germany) illustrates interlinked business and residential location choices. Turkish entrepreneurs are staying put because of their local networks and social embeddedness, investing in private and business properties in ethnic enclaves (Hanhörster, 2015). Households wellendowed with resources can also use their existing networks to make things easier for newcomers, thereby relativizing the negative effects attributed to the neighbourhood context (Barwick, 2016; Hanhörster, 2015).

Relatedly, and despite the fact that many arrival areas continue to be among the more disadvantaged, the diversity of newcomers is growing, extending the spectrum of available social, economic and cultural resources. Whereas migration research previously tended to differentiate between a transnational elite of high-qualified and mobile professionals and a less-endowed cohort of non-mobile workers, we are now seeing a blurring of this dichotomy, with an increasing number of migrants of middle-class backgrounds. While they might be migrating with little financial capital, many of them possess high cultural and social capital, which affects the way in which they are able to access resources (Ryan, 2011).

These recent studies point to the contribution which an arrival infrastructural lens could potentially make to studies on context effects and ethnic enclaves, with increased attention paid to a) the role of inter-ethnic support networks and long-established migrants in filling structural deficits, and b) access to resources which, 
albeit often initiated within an arrival area, go beyond the neighbourhood.

The next two sections look in greater detail at the conceptual understanding of arrival areas and empirical evidence highlighting specific features and dynamics attributed to them.

\section{Arrival Areas and Arrival Infrastructures: Conceptual Understandings}

Even in times of easier mobility, new digital forms of communication and migrants' embeddedness in transnational networks, localities and physical-spatial infrastructures continue to play a major role in catering for local populations (Zapata-Barrero, Caponio, \& Scholten, 2017). Virtual networks are by no means doing away with the need for local contacts, but instead complement such contacts and can help with navigating different pathways for local integration (Hsiao \& Dillahunt, 2018; Sametipour, 2017). Support and assistance for dealing with everyday situations continue to be provided in the immediate surroundings. This holds true not only for lowincome groups but also for high-skilled migrants: "The importance of proximity will persist for services until it is possible to transport a cup of sugar electronically" (Plickert, Côté, \& Wellman, 2007, p. 424).

A growing body of literature examines social relations and encounters in urban areas characterized by ongoing immigration. Studies on 'everyday multiculturalism' (Wise \& Velayutham, 2009) have focused on a wide spectrum of social relations which people form across differences, illustrating new forms of inclusion and exclusion in such contexts (Noble, 2009; Wessendorf, 2019; Wise, 2009). While these studies have looked more generally at social life in super-diverse areas, recent work on arrival areas and arrival infrastructures has more specifically investigated how conditions of long-term immigration shape newcomers' processes of arrival and, possibly, settlement. Doug Saunders' book (2011) Arrival City is a good starting point for any debate on arrival areas and arrival infrastructures. He uses examples taken from arrival contexts across the globe to illustrate migrants' arrival conditions and integration processes in cities. While Saunders (2011) understands 'arrival' primarily through the lens of upwards social mobility, we define it (in the sense of our understanding of integration) as access to functional, social and symbolic resources. Saunders turns our attention to local factors influencing the access of various immigrant groups to resources and how such processes can enhance their long-term integration. Despite the wide range of local conditions in different (national) contexts, he identifies overarching patterns and functions characterising arrival areas.

Public institutions and social infrastructures (such as advice centres or language courses) within walking distance can play a decisive role in the arrival process and further integration of residents (Saunders, 2011, p. 58). In addition, a certain housing density and pub- lic spaces close to their homes can offer migrants opportunities to meet others and are thus important contexts for building social contacts and potentially social capital (Farwick, Hanhörster, Ramos Lobato, \& Striemer, 2019 , p. 13). Many arrival areas are characterised by a high density of social networks, whether linking home and host country contexts or establishing ties to other urban contexts (Saunders, 2011, pp. 22-23). Thus, arrival areas can also be described as hubs within cities where a concentration of resources for new arrivals can be found. They can provide newcomers with social networks for accessing societal resources as well as housing and work (Hans et al., 2019). In addition, they allow ties to migrants' home countries, for instance via existing infrastructures for transferring goods or information such as money transfer agencies, Internet cafes, etc.

Building on Saunder's idea of arrival cities, an emerging body of social scientific literature has developed the notion of 'arrival areas' and 'arrival infrastructures.' Kurtenbach (2015) has drawn up a characterisation of 'arrival areas' in the German context, describing such areas as urban neighbourhoods shaped by socio-economic disadvantage, high numbers of migrants and high fluctuation rates. The idea of 'arrival infrastructures' builds on Xiang and Lindquist's concept of migration infrastructures, defined as "the systematically interlinked technologies, institutions, and actors that facilitate and condition mobility" (Xiang \& Lindquist, 2014, p. 124). Arrival infrastructures include, for example, migrant-run businesses as information hubs, hairdressers, mosques, associations or language classes, often set up by people who themselves have a migration background (Schmiz \& Kitzmann, 2017). Importantly, arrival infrastructures also include individuals who take on an instrumental role in newcomers' settlement, here conceptualised as 'arrival brokers.' The notion of 'arrival brokers' draws on Lindquist, Xiang, and Yeoh's definition of 'migrant brokers' as a "party who mediates between other parties" (2012, p. 7), for example between a newcomer and employer.

Importantly, Saunders stresses that not all migrant inflows into cities result in the emergence of 'successful' arrival areas. Resource access can be understood as an organisationally embedded process (Small, 2009). The permeability of institutions and local organisations' internal routines shape the nature of newcomers' first steps in the host country and determine whether they manage to move up the social ladder (Saunders, 2011, p. 63), as seen in the housing sector. Various studies have demonstrated migrants' limited access to the housing market in several (European) countries (Auspurg, Schneck, \& Hinz, 2018). The declining stock of social housing as well as institutional cultures, such as institutional routines and the blocking strategies of housing providers, contribute to the further marginalisation of specific groups. At present, asylum-seekers and refugees in particular are facing major problems on the housing market (Czischke \& Huisman, 2018). Research shows that even long-established immigrants and their children- 
even though upwardly mobile and now members of the middle classes-still face barriers on the housing market. Thus, the ability to settle and remain in arrival areas, or 'move on' within the wider city context, is shaped by the institutional environment and local (housing) politics (Barwick, 2016; Hanhörster, 2015).

Importantly, the housing market also plays a major role in the emergence of new arrival areas, for example in urban peripheries and suburbs where newcomers might be able to access cheaper housing (Keil, 2017; Tzaninis, 2019). Arrival areas are thus not necessarily a unique feature of large metropolises but can also be found in 'ordinary' cities (Hall, 2015; Robinson, 2006), for example non-metropolitan areas or intermediate cities. For example, through policies of dispersion at European, national and regional levels, small and medium-sized cities have (re)appeared as places active in the arrival and incorporation of migrants. Hence, a range of city and suburban spaces beyond the big metropolises can function as arrival areas where emerging arrival infrastructures and arrival brokers can be found.

\section{Empirical Research on Arrival Areas: Characteristics and New Dynamics}

Research into arrival processes in cities and neighbourhoods with high migrant populations has gained pace in recent years (Meeus et al., 2019). Providing resources such as services for newcomers (e.g., international money transfers), casual work in non-knowledge sectors (Kurtenbach, 2015), and access to affordable housing, arrival neighbourhoods offer important opportunities for migrants to gain a foothold in their new country. Using Istanbul's inner-city neighbourhood Kumkapı as an example, Biehl (2014) looks at the characteristics and dynamics of an 'arrival neighbourhood,' describing it as a highly diversified area which has become an anchor point for different cohorts of migrants, the composition of which is constantly evolving in the face of ongoing in and out movement. The area is characterised by informal structures, offering migrants-in addition to access to housing - a range of arrival resources such as access to employment. Often, the brokering of jobs and housing goes beyond co-ethnic networks, occurring between long-established migrants and newcomers. Current studies in arrival areas in Germany and Belgium confirm the special role of local arrival-specific infrastructures offering newcomers hassle-free access to support services (Kurtenbach, 2015; Schillebeeckx, Oosterlynck, \& de Decker, 2019). Immigrants in such neighbourhoods often enjoy the support of long-established migrants in the form of social networks and local infrastructures (e.g., migrant-run businesses). Such networks sometimes also facilitate access to resources (such as jobs, advice centres or religious institutions) located outside the neighbourhood.

Using Antwerpen-Noord as their example, Schillebeeckx et al. (2019) examine the extent to which arrival infrastructures provide resources for newcomers, showing that the neighbourhood, in addition to offering housing for people on the poverty line, also provides opportunities for informal work. Such work is found by the newcomers via well-oiled social networks and with the help of NGOs. The authors conclude that the spatial concentration of long-established migrants in a neighbourhood is a factor promoting the chances of newcomers to find their feet in their new environment. Recent research has also shown newly emerging forms of solidarity between settled and incoming migrants, revealing how newcomers often draw on other migrants' know-how regarding information about access to services, housing and jobs and knowledge of the legal system, for example between migrants with refugee status and asylum seekers (Phillimore et al., 2018; Wessendorf \& Phillimore, 2019). These findings speak to the emerging work on informal arrival infrastructures provided by settled individuals or groups, also conceptualised as 'people as infrastructures' (Simone, 2004), 'migrant infrastructures' (Hall, King, \& Finlay, 2017), 'soft infrastructures' (Boost \& Oosterlynck, 2019) and 'infrastructures of superdiversity' (Blommaert, 2014). To a large extent shaped by social support networks and forms of social capital, such infrastructures are contingent on the nature of social relations between long-established residents and newcomers.

While, by its nature, the concept of arrival infrastructures focuses on the materiality of arrival and settlement resources (i.e., the physical presence of such infrastructures), the mobility and fluctuation rates found in urban arrival areas also mean that arrival infrastructures often transcend neighbourhood boundaries. Institutions such as mosque associations or doctors' surgeries are not only used by local populations, but in many cases attract established migrants who have since moved away from the neighbourhood (Hanhörster \& Weck, 2016). Empirical studies in Germany have looked at the social ties developed in certain institutions such as mosques and community organisations and in many cases transcending neighbourhood boundaries, illustrating the permeability of (administrative) neighbourhood boundaries (Hanhörster \& Weck, 2016).

Alongside the functional aspect of supplying neighbourhood residents with information, goods and services, infrastructures such as advice centres or (migrant) organisations can also provide important forms of informal help. Such personal services can involve the transfer of more informal information or the provision of emotional support but may also involve resources helping newcomers to start climbing up the social ladder (Farwick et al., 2019). The density and configuration of these settings influence the social and cultural resources of neighbourhood residents in many ways. For example, research on arrival areas in Dortmund and Hannover has illustrated the importance of 'weak ties' (Granovetter, 1973) and their ability to also provide resources going beyond just 'getting-by.' The qualitative results illustrate the relevance of the right 'interfaces' for transferring re- 
sources: For resources promoting upward social mobility to be transferred, it is not enough to simply have contact with partners well-endowed with such resources, but partners also need to possess knowledge about relevant services or available jobs or housing (Farwick et al., 2019: p. 13; Phillimore et al., 2018).

Institutionalised to varying degrees, these settings play an important role as hubs allowing people to come together and as sites for transferring social, cultural and economic capital (Kurtenbach, 2015; Schillebeeckx et al., 2019). Drawing on research on several high streets in the UK characterised by high numbers of businesses run by migrants, Hall et al. (2017, p. 1325) describe how "the migrant infrastructure of the street offers a partial promise to the newcomer, a space of relative autonomy and invisibility, to obtain a foothold in the city." They describe how some shopkeepers have taken on the important function of helping newcomers with filling in official forms.

Ongoing research in East London, undertaken by Wessendorf, has shown the importance of the visibility of services for migrant newcomers. Especially migrants with little knowledge of the majority language and limited digital literacy often find support just by walking around an area and seeing support services advertised in public space. One of the local libraries, for example, sports a large sign and a huge window through which people can see that it is a publicly accessible space offering various types of advice services. Due to its high visibility and welcoming atmosphere, many newcomers enter the library to gain information on services such as language classes or welfare advice. For many, the library thus functions as a steppingstone to other types of support. An arrival infrastructural approach thus highlights the spatial and material dimensions of migrant arrival, building on calls to "rethink the role of materiality" (Burchardt \& Hoehne, 2015, p. 5) in social life (Seethaler-Wari, 2018, p. 147).

Importantly, arrival areas can offer access to resources transcending ethnic boundaries. In such contexts, long-established migrants with 'settlement expertise' can support newcomers of various backgrounds to find a foothold in a new place (Phillimore et al., 2018). Thus, migrants act as 'arrival brokers' in different fields, bridging 'structural holes' (Burt, 1992) within and outside the neighbourhood and providing access to settlement information.

However, arrival infrastructures do not always generate forms of social capital or access to functional support. They can also enhance forms of exclusion. For example, the second-hand car trade in one area in Brussels was set up by particular groups of newcomers decades ago. While it offers employment for newcomers, it also locks some of them into low-paid jobs, particularly those with an insecure legal status (Meeus \& Arnaut, 2019). Similarly, research in East London undertaken by Wessendorf has shown that newcomers sometimes get stuck in poorly paid jobs, for example in the building sector, due to limited knowledge of English and dependence on co-ethnic 'gatekeepers' who channel them into specific jobs. Andersson, Musterd, and Galster (2019) investigated refugees' employment prospects in so-called portof-entry neighbourhoods in Sweden, identifying gender differences and illustrating how female refugees' labour market participation is negatively affected by greater percentages of co-ethnic neighbours and social pressures to refrain from taking up paid work. Taking the housing market as an example, recent research in Germany points to informal letting strategies leading to an overcrowding of newly arriving migrants in dilapidated buildings, taking advantage of Romanian and Bulgarian migrants' weak position on the housing market (Hanhörster, Ramos Lobato, Droste, Diesenreiter, \& Becker, 2020). Arrival neighbourhoods and arrival-specific infrastructures can thus be both enabling and disabling with regard to social mobility.

\section{Conclusion: Arrival Infrastructures as Crystallisation Points for Transferring Resources}

This article has provided a conceptual overview of the notion of arrival areas and how such areas potentially offer a wealth of arrival infrastructures through which newcomers can access arrival and settlement resources. Previous research on neighbourhoods with high numbers of people with a migration background, primarily in the realm of studies on so-called 'context effects' and 'ethnic enclaves,' has described both the advantages and disadvantages of living in such areas. Because much of the research on 'context effects' has assumed that deprivation in such neighbourhoods leads to further disadvantage (van Ham \& Manley, 2012), and that, for local authorities, the arrival of newcomers might exacerbate already existing challenges related to deprivation, many European countries are applying distribution strategies in order to disperse newly arriving refugees (Adam et al., 2020; ESPON, 2019).

While research on neighbourhood effects has looked at the effects of disadvantage on the population at large (including people with a migration background), and research on ethnic enclaves has tended to look at longestablished migrants and ethnic minorities, research on arrival areas more specifically focuses on how the neighbourhood context affects recently arrived migrant newcomers. This is particularly relevant in a time when newcomers often settle in areas populated by previous migrants, but not necessarily by people from the same background. The arrival infrastructural lens thus enables an analysis of migrant integration which goes beyond assumptions of co-ethnic support, looking at how arrival infrastructures, set up by long-established migrants, might benefit newcomers from various backgrounds. Thus, the spatial concentration of immigrants can facilitate the social participation of newly arrived migrants and their access to arrival resources (Hanhörster \& Weck, 2016; Kurtenbach, 2015; Schillebeeckx et al., 2019). Nevertheless, the focus on arrival infrastructures 
must not overlook the existence of precarity and multiple disadvantages among those living in such areas. In fact, arrival infrastructures providing support for newcomers often emerge because of underlying disadvantage and discrimination, for example regarding access to housing. Long-established migrants thus fill structural holes resulting from limited welfare provision and lack of urban planning by local government.

Using this perspective on how migrants gain access to resources puts the effects of existing disadvantages into a different light. Dependent on how urban institutions are structured and which local alliances exist, the specific functionalities offered by arrival spaces need to be acknowledged and strengthened. Local governments and urban planners could build on long-established migrants' (often informal) arrival know-how, supporting them in providing access to resources and settlement information for newcomers. With migrants actively participating in many ways in both informal and formal networks, we need further research on migrant networks and the strategies with which migrants gain access to resources upon arrival (see for example Phillimore et al., 2014; Ryan, 2011).

This specific focus on arrival areas and their characteristics also speaks against integration policies which assume that migrants should 'integrate' into a supposed 'mainstream society' which, in areas of long-term immigration, is difficult to define (Grzymala-Kazlowska \& Phillimore, 2017). This focus on arrival areas shifts attention-dominant in integration theory and policyaway from the individual migrant and towards the role of the resources provided in specific areas. Resulting from a lack of local government support structures, it is often long-established populations, including those with a migration background themselves, who step in and fill structural holes. The arrival infrastructural lens thus contributes to our understanding of migrant integration processes shaped not only by newcomers' own social, cultural and economic capital and by broader national and city-wide integration policies, socio-economic conditions and support structures (or the lack thereof), but also by the presence of long-established migrants and ethnic minorities with specific settlement expertise. It is this specific expertise as 'arrival brokers' which many newcomers tap into upon arrival.

A more detailed analysis of the dynamics and mechanisms found in arrival areas extends static concepts of territorially bounded neighbourhoods whose residents are seen to be primarily influenced by their disadvantageous surroundings, and relativizes the negative effects of living in 'disadvantaged neighbourhoods' discussed in research on context effects. This new perspective applies especially to the social, institutional and spatially related functional ties extending beyond neighbourhood boundaries. The societal processes currently emerging in neighbourhoods with high migrant populations cannot be covered sufficiently by research focused solely on neighbourhood context effects. Looking at arrival areas and specif- ically at the everyday practices of the people living in these areas enables us to show how different transnational and multilocal migration and settlement practices provide scope for social participation. Through researching arrival areas, the functions of certain spaces in our cities for integrating migrants can be understood in a wider context, as can the constitutive and transformational power of migration and its influence on urban development practices.

Further studies of urban peripheries and 'ordinary cities' could illustrate their role as increasingly relevant contemporary arrival spaces. Although the specific spatial features and social practices described here have been observed in many different case studies throughout the world, a discussion of the quantitative and qualitative indicators needed to identify arrival spaces has only taken place in a handful of European cities. And finally, further research is needed to both identify established and incipient arrival spaces, and to look more closely at the lifestyles, individual practices and social interactions of migrants in increasingly diverse neighbourhoods, thereby gaining a better understanding of the many facets of arrival and integration.

\section{Acknowledgments}

We would like to thank the anonymous reviewers for their constructive comments and suggestions on the earlier version of this article. Some of the ideas and arguments developed in this article draw on a German publication to which one of the authors contributed (Hans et al., 2019).

\section{Conflict of Interests}

The authors declare no conflict of interests.

\section{References}

Adam, F., Föbker, S., Imani, D., Pfaffenbach, C., Weiss, G., \& Wiegandt, C. C. (2020). Municipal housing strategies for refugees: Insights from two case studies in Germany. In B. Glorius \& J. Doomernik (Eds.), Geographies of asylum in Europe and the role of European localities (pp. 201-223). Cham: Springer International Publishing.

Ager, A., \& Strang, A. (2008). Understanding integration: A conceptual framework. Journal of Refugee Studies, 21(2), 166-191.

Andersson, R., Musterd, S., \& Galster, G. (2019). Port-ofentry neighbourhood and its effects on the economic success of refugees in Sweden. The International Migration Review, 53(3), 671-705.

Auspurg, K., Schneck, A., \& Hinz, T. (2018). Closed doors everywhere? A metaanalysis of field experiments on ethnic discrimination in rental housing markets. Journal of Ethnic and Migration Studies, 45(1), 1-20. https://doi.org/10.1080/1369183X.2018.1489223 
Barwick, C. (2016). Social mobility and neighbourhood choice: Turkish-Germans in Berlin. London and New York, NY: Routledge.

Biehl, K. S. (2014). Exploring migration, diversification and urban transformation in contemporary Istanbul: The case of Kumkapı (Working Paper No. 14-11). Göttingen: The Max Planck Institute for the Study of Religious and Ethnic Diversity.

Blommaert, J. (2014). Infrastructures of superdiversity: Conviviality and language in an Antwerp neighbourhood. European Journal of Cultural Studies, 17(4), 431-451.

Boost, D., \& Oosterlynck, S. (2019). 'Soft' urban arrival infrastructures in the periphery of metropolitan areas: The role of social networks for sub-Saharan newcomers in Aalst, Belgium. In B. Meeus, K. Arnaut, \& B. van Heur (Eds.), Arrival infrastructures: Migration and urban social mobilities (pp. 153-177). London and New York, NY: Palgrave Macmillan.

Burchardt, M., \& Hoehne, S. (2015). The infrastructures of diversity: Materiality and culture in urban space: An introduction. New Diversities, 17(2), 1-13.

Burt, R. S. (1992). The social structure of competition: Structural holes. London and Cambridge, MA: Harvard University Press.

Czischke, D., \& Huisman, C. J. (2018). Integration through collaborative housing? Dutch starters and refugees forming self-managing communities in Amsterdam. Urban Planning, 3(4), 156-165. http://dx.doi.org/ 10.17645/up.v3i4.1727

Erel, U. (2011). Complex belongings: Racialization and migration in a small English city. Ethnic and Racial Studies, 34(12), 2048-2068.

ESPON. (2019). MIGRARE: Impacts of refugee flows to territorial development in Europe (Final Report). Luxembourg: ESPON. Retrieved from https://www. espon.eu/sites/default/files/attachments/ MIGRARE_Final_Report.pdf

Faist, T. (2015). Transnational social spaces. Ethnic and Racial Studies, 38(13), 2271-2274. https://doi.org/ 10.1080/01419870.2015.1058502

Fajth, V., \& Bilgili, Ö. (2018). Beyond the isolation thesis: Exploring the links between residential concentration and immigrant integration in the Netherlands. Journal of Ethnic and Migration Studies, 1(25). https://doi.org/10.1080/1369183X.2018.1544067

Farwick, A., Hanhörster, H., Ramos Lobato, I., \& Striemer, W. (2019). Neighbourhood-based social integration: The importance of the local context for different forms of resource transfer. Spatial Research and Planning, 77(4), 1-18.

Galster, G. (2007). Neighbourhood social mix as a goal of housing policy: A theoretical analysis. European Journal of Housing Policy, 7(1), 19-43.

Galster, G., \& Sharkey, P. (2017). Spatial foundations of inequality: A conceptual model and empirical overview. The Russell Sage Foundation Journal of the Social Sciences, 3(2), 1-33.
Glick Schiller, N., \& Çağlar, A. (2009). Towards a comparative theory of locality in migration studies: Migrant incorporation and city scale. Journal of Ethnic and Migration Studies, 35(2), 177-202.

Granovetter, M. S. (1973). The strength of weak ties. American Journal of Sociology, 78(6), 1360-1380.

Grzymala-Kazlowska, A., \& Phillimore, J. (2017). Introduction: Rethinking integration. New perspectives on adaptation and settlement in the era of superdiversity. Journal of Ethnic and Migration Studies, 44(2), 179-196.

Hall, S. (2015). Migrant urbanisms: Ordinary cities and everyday resistance. Sociology, 49(5), 853-869.

Hall, S., King, J., \& Finlay, R. (2017). Migrant infrastructure: Transaction economies in Birmingham and Leicester, UK. Urban Studies, 54(6), 1311-1327. https://doi.org/10.1177/0042098016634586

Hanhörster, H. (2015). Should I stay or should I go? Locational decisions and coping strategies of Turkish homeowners in low-income neighbourhoods. Urban Studies, 52(16), 3106-3122.

Hanhörster, H., Ramos Lobato, I., Droste, C., Diesenreiter, C., \& Becker, A. (2020). Faire Wohnraumversorgung und "gesunde Mischung"? [Fair provision of housing and a 'healthy mix'?]. Berlin: vhw-Bundesverband für Wohnen und Stadtentwicklung e.V. Retrieved from https://www.vhw.de/fileadmin/user_upload/ 08_publikationen/verbandszeitschrift/FWS/2020/ 2_2020/FWS_2_20_Hanhoerster_et_al.pdf

Hanhörster, H., \& Weck, S. (2016). Cross-local ties to migrant neighborhoods: The resource transfers of outmigrating Turkish middle-class households. Cities, 59, 193-199.

Hans, N., Hanhörster, H., Polivka, J., \& Beißwenger, S. (2019). Die Rolle von Ankunftsräumen für die Integration Zugewanderter [The role of arrival areas for migrant integration]. Raumforschung und Raumordnung, 77(5), 1-14.

Hsiao, J. C.-Y., \& Dillahunt, T. R. (2018). Technology to support immigrant access to social capital and adaptation to a new country. Proceedings of the ACM on Human-Computer Interaction, 2(70), 1-21.

Keil, R. (2017). Suburban planet: Making the world urban from the outside. Hoboken, NJ: John Wiley \& Sons.

Kurtenbach, S. (2015). Ankunftsgebiete: Segregration als Potenzial nutzen [Arrival areas: Using segregation as potential]. In A. El-Mafaalani, S. Kurtenbach, \& K. P. Strohmeier (Eds.), Auf die Adresse kommt es an [It all depends on the address] (pp. 306-328). Weinheim and Basel: Beltz Juventa.

Lindquist, J., Xiang, B., \& Yeoh, B. S. (2012). Opening the black box of migration: Brokers, the organization of transnational mobility and the changing political economy in Asia. Pacific Affairs, 85(1), 7-19.

Meeus, B., \& Arnaut, K. (2019). Migration and the infrastructural politics and struggles of arrival. Paper presented at the Annual Conference of the European Network of Excellence on International Migration, In- 
tegration and Social Cohesion, Malmö, Sweden.

Meeus, B., Arnaut, K., \& van Heur, B. (Eds.). (2019). Arrival infrastructures: Migration and urban social mobilities. London and New York, NY: Palgrave Macmillan.

Noble, G. (2009). Everyday cosmopolitanism and the labour of intercultural community. In A. Wise \& S. Velayutham (Eds.), Everyday multiculturalism (pp. 46-65). Basingstoke: Palgrave Macmillan.

Ostendorf, W., \& Musterd, S. (2011). Ethnic minorities in Amsterdam: Trapped or mobile? In B. Ludger (Ed.), Zwischen Basel, Bochum und Toronto: Einblicke in die Geographie postindustrieller Stadtentwicklung [Between Basel, Bochum and Toronto: Insights into the geography of post-industrial urban development] (pp. 53-82). Münster: LIT Verlag.

Phillimore, J., Humphris, R., \& Khan, K. (2014). Migration, networks and resources: The relationship between migrants' social networks and their access to integration resources. Milan: Fondazione ISMU.

Phillimore, J., Humphris, R., \& Khan, K. (2018). Reciprocity for new migrant integration: Resource conservation, investment and exchange. Journal of Ethnic and Migration Studies, 44(2), 215-232.

Plickert, G., Côté, R. R., \& Wellman, B. (2007). It's not who you know, it's how you know them: Who exchanges what with whom? Social Networks, 29(3), 405-429. https://doi.org/10.1016/j.socnet.2007.01.007

Portes, A., \& Manning, R. D. (1986). The immigrant enclave: Theory and empirical examples. In S. Olzak \& J. Nagel (Eds.), Competitive ethnic relations (pp. 47-68). Cambridge, MA: Academic PR.

Robinson, J. (2006). Ordinary cities: Between modernity and development. London and New York, NY: Routledge.

Robinson, V., Andersson, R., \& Musterd, S. (2003). Spreading the "burden"? A review of policies to disperse asylum seekers and refugees. Bristol: Policy Press.

Ryan, L. (2011). Migrants' social networks and weak ties: Accessing resources and constructing relationships post-migration. Sociological Review, 59(4), 707-724.

Sametipour, A. (2017). Ethnographic study of Facebook usage among the Persian and Arabic-speaking refugees and asylum seekers in asylum center in Utrecht. Medienimpulse, 55(3), 1-40.

Saunders, D. (2011). Arrival city: How the largest migration in history is reshaping our world. London: William Books.

Schillebeeckx, E., Oosterlynck, S., \& de Decker, P. (2019). Migration and the resourceful neighborhood: Exploring localized resources in urban zones of transition. In B. Meeus, K. Arnaut, \& B. van Heur (Eds.), Arrival infrastructures (pp. 131-152). London: Palgrave Macmillan.

Schmiz, A., \& Kitzmann, R. (2017). Negotiating an Asiatown in Berlin: Ethnic diversity in urban planning. Cities, 70, 1-10.
Seethaler-Wari, S. (2018). Urban planning for the integration of refugees: The importance of local factors. Urban Planning, 3(4), 141-155. https://doi.org/ 10.17645/up.v3i4.1696

Simone, A. (2004). People as infrastructure: Intersecting fragments in Johannesburg. Public Culture, 16(3), 407-429.

Slater, T. (2013). Your life chances affect where you live: A critique of the 'cottage industry' of neighbourhood effects research. International Journal of Urban and Regional Research, 37(2), 367-387.

Small, M. L. (2009). Unanticipated gains: Origins of network inequality in everyday life. Oxford and New York, NY: Oxford University Press.

Tzaninis, Y. (2019). Cosmopolitanism beyond the city: Discourses and experiences of young migrants in postsuburban Netherlands. Urban Geography. https:// doi.org/10.1080/02723638.2019.1637212

van Ham, M., \& Manley, D. (2012). Neighbourhood effects research at a crossroads: Ten challenges for future research introduction. Environment and Planning $A$, 44, 2787-2793.

van Kempen, R., \& Wissink, B. (2014). Between places and flows: Towards a new agenda for neighbourhood research in an age of mobility. Geografiska Annaler: Series B, Human Geography, 96(2), 95-108.

Vaughan, S. (2007). The spatial foundations of community construction: The future of pluralism in Britain's 'multi-cultural' society. Global Built Environment Review, 6(2), 3-17.

Vertovec, S. (2007). Super-diversity and its implications. Ethnic and Racial Studies, 30(6), 1024-1054.

Vertovec, S. (2015). Diversities old and new: Migration and socio-spatial patterns in New York, Singapore and Johannesburg. London: Palgrave Macmillan.

Wessendorf, S. (2019). Pioneer migrants and their social relations in super-diverse London. Ethnic and Racial Studies, 42(1), 17-34.

Wessendorf, S., \& Phillimore, J. (2019). New migrants' social integration embedding and emplacement in superdiverse contexts. Sociology, 53(1), 1-16.

Wilson, K. L., \& Martin, W. A. (1982). Ethnic enclaves: A comparison of the Cuban and Black economies in Miami. American Journal of Sociology, 88(1), 135-160.

Wise, A. (2009). Everyday multiculturalism: Transversal crossings and working-class cosmopolitans. In A. Wise \& S. Velayutham (Eds.), Everyday multiculturalism (pp. 21-43). Basingstoke: Palgrave Macmillan.

Wise, A., \& Velayutham, S. (Eds.). (2009). Everyday multiculturalism. Basingstoke: Palgrave Macmillan.

Xiang, B., \& Lindquist, J. (2014). Migration infrastructure. International Migration Review, 48(1), 122-148.

Zapata-Barrero, R., Caponio, T., \& Scholten, P. (2017). Theorizing the 'local turn' in a multi-level governance framework of analysis: A case study in immigrant policies. International Review of Administrative Sciences, 83(2), 241-246. https://doi.org/10.1177/ 0020852316688426 
Zhou, M. (2009). How neighbourhoods matter for immigrant children: The formation of educational resources in Chinatown, Koreatown and Pico Union,
Los Angeles. Journal of Ethnic and Migration Studies, 35(7), 1153-1179. https://doi.org/10.1080/ 13691830903006168

\section{About the Authors}

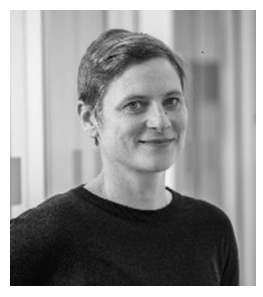

Heike Hanhörster is Senior Researcher at ILS-Research Institute for Regional and Urban Development in Dortmund, Germany. Her research interest covers place-based processes of social inclusion and exclusion and people's encounters with difference. Her recent research includes social networks of households in low-income neighbourhoods, institutional discrimination and exclusionary processes on the housing market, middle-class disaffiliation strategies as well as neighbourhood choice and affiliations of Turkish middle-class households.

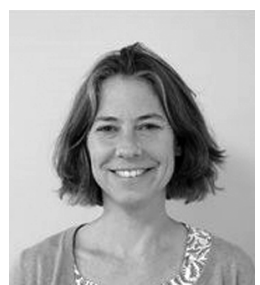

Susanne Wessendorf is Associate Professorial Research Fellow at the International Inequalities Institute, London School of Economics and Political Science, and Associate Professor at Coventry University's Centre for Trust, Peace and Social Relations. Her work focuses on understanding new forms of social inclusion and exclusion in contexts of immigration-related diversity. 